\title{
Contents, Vol. 184, 1982
}

No. 1 Original Paper · Travaux originaux $\cdot$ Originalarbeiten

L'herpès oculaire de Tenfant

Colin, J.; Le Grignou, M.; Le Grignou, A.; Renard, G.; Chastel, C 1

Tuberculose miliaire choroïdienne: Etude angiofluorographique

Santoni, G.; Fiore, C; Lupidi, G.; Galuppo, L 6

Dystrophia retinae pigmentosa, Fundus flavimaculatus and Stargardt's Disease in One

Family

Meel, G.J. van; Winkelman, J.E 13

Our Experience in the Treatment of the Irvine-Gass Syndrome

Arciniegas, C.A.; Mosqueda, F.M 21

Photocoagulation of Optic Disc Pits

Kottow, M 26

La dysversion papillaire. Diagnostic différentiel du syndrome chiasmatique

Dimitrakos, S.A.; Safran, A.B 30

Kearns Syndrome or Kearns Disease. Further Evidence of a Genuine Entity in a Case with

Uncommon Features

Bastiaensen, L.A.K.; Notermans, S.L.H.; Ramaekers, C.H.; Dijke, BJ. van; Joosten,

E.M.G.; Jaspar, H.H.J.; Stadhouders, A.M.; Beljaars, C.T.E 40

Lanthony's New Color Test. IV. Neutral Zone and Neutral Grays

Pinckers, A 51

Book Reviews $\cdot$ Livres nouveaux $\cdot$ Buchbesprechungen 58

No. 2 Original Paper Travaux originaux — Originalarbeiten

Genetics of Cataract

Francois, J 61

Visusbesserung infolge Arteria-ophthalmica-Ligatur. Beitrag zur Therapie der Arteritis temporalis und okularer Durchblutungsstörungen

Gramberg-Danielsen, B 72

Hereditary Microphthalmos Associated with Ichthyosis. A Genetic, Clinical, Ultrasonographic and Histological Study

Loffredo, A.; Cennamo, G.; Cecio, A.; Federico, A.; Sammartino, A

Functional Exploration of the Lacrimal Gland by Tear Electrophoresis

Liotet, S.; Warnet, V.N.; Arrata, M 87

Trimethoprim-Polymyxin Eye Drops versus Neomycin-Polymyxin-Gramicidin Eye Drops in the Treatment of Presumptive Bacterial Conjunctivitis - a Double-Blind Study

Genée, E.; Schlechtweg, C; Bauerreiss, P.; Gibson, J.R 92

A Rare Presentation of Bilateral Membranous Conjunctivitis in Dermatomyositis

Sammartino, A.; Lucariello, A.; Esposito, L.; Vetrano, A.; Loffredo, A 97

Elektroophthalmologische Befunde bei Optikusatrophien verschiedener Genese

Teping, C; Schnaudigel, O.E 103 
Tear Calcium Levels in Normal Subjects

Caldeira, J.A.F.; Luthold, W.W.; Sabbaga, E114

Book Reviews · Livres nouveaux $\mathbf{a}$ Buchbesprechungen

120

IV

Index

No. 3 Original Paper $\cdot$ Travaux originaux $\cdot$ Originalarbeiten

Treatment of Malignant Choroidal Melanomas by Photocoagulation

Francois, J 121

Critical Evaluation of Corneal Graft Surgery Using Fresh Corneas and Corneas Preserved in MK-Medium

Sayegh, F.N 131

Ocular Manifestations in Thalassemia Minor

Magli, A.; Fusco, R.; Mettivier, V.; Pisapia, R

Densitometric Control of Retinal Vascular Reactions after Mandibular Nerve Anesthesia

Goder, G.J.; Nitzschke, M.; Ungethum, K.H 147

Protein Glaucoma - Overtaxing of Flow Mechanisms? Preliminary Report

Zirm, M 155

Binokularsehen einseitig Aphaker in Abhängigkeit vom Typ des Linsenersatzes

Oggel, K.; Neuhann, Th 162

On and Off Contribution to the Combined Occipital On-Off Response to a Pattern Stimulus

Crevits, L.; Lith, G. van; Vijfvinkel-Bruinenga, S 169

Lactic Deshydrogenase Isoenzymes in the Ocular Tissues and Liquids

Jacq, C; Liotet, S.; Warnet, V.N.; Arrata, M 174

Book Reviews $\cdot$ Livres nouveaux $\cdot$ Buchbesprechungen 179

No. 4 Original Paper · Travaux originaux Originalarbeiten

Reliefbilder des hinteren Augenpols

Miszalok, V.; Wollensak, J 181

A New Technique for the Anatomical Study of the Choroidal Blood Vessels

Ducournau, D.H 190

Role of the $\beta$-Adrenergic Receptor-Blocking Agent 'Timolo $\Gamma$ in the Treatment of Open-Angle

Glaucoma

Strempel, $1 \quad 198$

Biphasic Action of Prostacyclin on Intraocular Pressure

Wizemann, A.; Ebinger, G.; Krey, H.; Wizemann, V 204

Temporary Use of Intraocular Silicone Oil in the Treatment of Detachment with Massive

Periretinal Proliferation. Preliminary Report (with 1 color plate)

Gonvers, M 210

Retinal Detachment and HLA Typing

Verbraeken, H.; De Sutter, E.; De Bie, S 219

Toxic Amblyopia Associated with Crohn's Disease

Douglas, J.G.; Douglas, A.; Bartholomew, R.S.; Munro, J.F223

Normal Values of the Basic Level of the Standing Potential and Its Light Rise

Momirov, D.; Lith, G.H.M. van; Torren, K. van der; Vijfvinkel-Bruinenga, S

A. Author Index Subject Index

232233 
